IRSH 6I (2016), Special Issue, pp. 71-92 doi:10.1017/S0020859016000456 (C) 2016 Internationaal Instituut voor Sociale Geschiedenis

\title{
Colonial Organization of Mine Labour in Charcas (Present-Day Bolivia) and Its Consequences (Sixteenth to the Seventeenth Centuries)
}

\author{
Raquel Gil Montero \\ National Council of Science and Technology, \\ Institute of Geography, History and Social Sciences, \\ National University of the Centre of Buenos Aires Province \\ Pinto 399, Tandil (Buenos Aires), Argentina \\ E-mail: raquelgilmontero@conicet.gov.ar \\ PAula C. Za ga L S K Y \\ National Council of Science and Technology, \\ Regional History Research Institute, National University of Jujuy \\ Otero 262, Jujuy, Argentina \\ and \\ University of Buenos Aires, Argentina \\ E-mail: pzagalsky@gmail.com
}

\begin{abstract}
This article analyses the changes in the organization of labour during the sixteenth and seventeenth centuries in colonial Charcas, present-day Bolivia, focusing on the role that different colonial authorities played in this process and its consequences. The Spanish took advantage of the pre-Hispanic organization of labour from the beginning of their conquest. However, in a colonial context, labour relations changed significantly, and the architect of those alterations was Viceroy Francisco de Toledo. We examine the transformations in mine labour carried out by the Spanish colonial polity; these had a significant effect not only on mining, but also on all labour relations in the southern colonial Andes.
\end{abstract}

\section{INTRODUCTION}

This article analyses changes in the organization of labour during the first two colonial centuries, focusing on the role played by the different colonial authorities in this process and its consequences. Our starting point is the reforms carried out by Viceroy Francisco de Toledo during the I 570s, while we also consider past labour organization. This allows us to cast light on the 
role the colonial authorities played in labour relations and how that role changed during Toledo's rule. Engaging with the broader framework of this special issue, we suggest that those colonial authorities were mobilizers and allocators of labour; only occasionally were they direct employers.

In this article, we understand Charcas - a term with multiple meanings in an operative way sensu Barnadas: ${ }^{\mathrm{I}}$ a historically cohesive territory, the central force of which was Potosí. Between I 542 and I776, Charcas was included in the Peruvian Viceroyalty and, after I 56I, it was the centre of the jurisdiction of the Royal Audience of Charcas (supreme court of justice). The geographical scope of our study extends from Lake Titicaca in the north to the southern border of present-day Bolivia, excluding those indigenous territories on the eastern lowlands that were not under external control at that time (Figure I). This complex territory, inhabited by a range of ethnic groups, was conquered by the Incas during the fifteenth century and during the I 530 s by the Spanish. The relationship those groups had with the Incas, and later on with the Spanish, varied from war to alliance, and the first colonial decades were especially conflictive.

Although mining activities began with the Spanish conquest, the exploitation of the most important centre, Potosí, did not get underway until I 545 , in the context of the civil war among the conquerors. In I 548 , the Crown managed to put an end to the rebellion, but the power of the local Spanish lords did not diminish until the arrival of the fifth Viceroy of Peru, Francisco de Toledo (I569-158I). Before Toledo, the Crown had granted privileges to particular Spaniards who had actually carried out the conquest. They were given rights (encomienda) to obtain tributes from the indigenous peoples, paid in the form of goods, silver, gold, labour, or personal services.

In this article, we focus especially on the changes made to the indigenous tributary system and on the forced mine labour, known as mita, which Toledo introduced for the Potosí silver mines and mills. Here, we want to stress one of the changes introduced by Toledo, namely dividing indigenous obligations into two: all indigenous tributaries (men between eighteen and fifty years' old) had to pay a monetary tribute to the Crown, and a proportion of those men had to work for Spaniards, mainly in mining activities, for a specific period of time (mita). The mita was a statecoordinated form of draft labour that influenced the lives of the majority of the indigenous population in Charcas, as we will see. These changes were central to the evolution of labour relations in the following century.

The seventeenth century saw a massive process of migration of indigenous peoples, caused by the changes mentioned above, since they were forced to obtain money to pay the tributes or to pay for a replacement

I. Josep M. Barnadas, Charcas, orígenes históricos de una sociedad colonial (La Paz, 1973). 


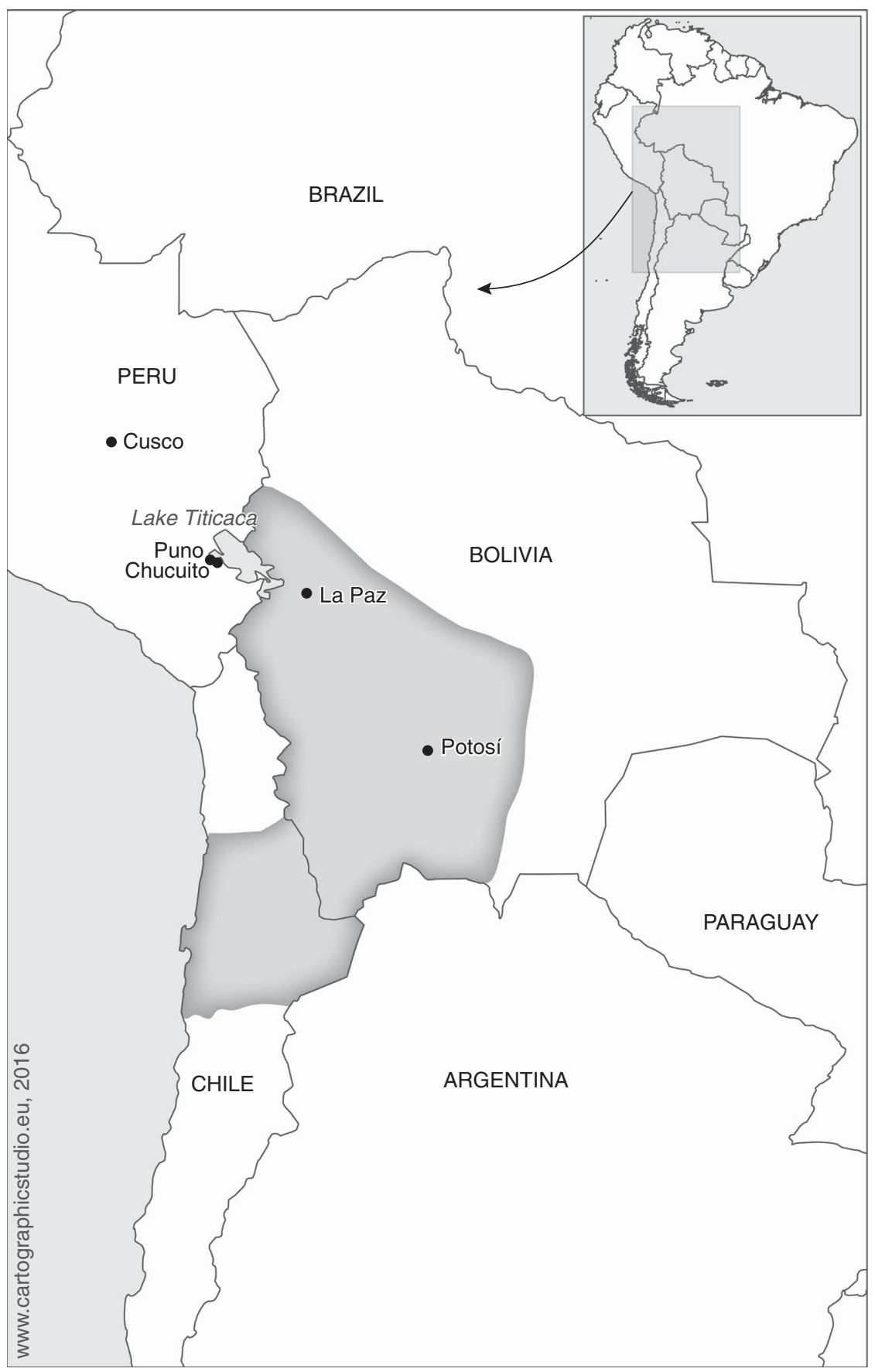

Figure I. Charcas during the seventeenth century. 
for the mita, or alternatively responded by running away from their ethnic authorities or colonial obligations. Despite migration posing complications concerning the payment of tributes, as well as concerning the observance of the mining mita system, the colonial authorities did not respond. We argue that an important causal factor in this official reticence was the fact that this massive indigenous migration process favoured the private acquisition of labour by the Spanish owners of other mines and haciendas, as well as of other productive activities. Hence, we examine the changes carried out to mine labour by the Spanish colonial polity and its consequences not only for mining, but also for all labour relations in the southern colonial Andes.

We have analysed a range of concepts, including tribute, payment, and free labour, within the framework of the taxonomy of labour relations developed by the Global Collaboratory on the History of Labour Relations (Collaboratory). In our final section, we will reflect upon the changes in labour relations in the light of this taxonomy.

\section{INITIAL ORGANIZATION OF COLONIAL LABOUR}

This section focuses on those aspects of the colonial labour organization that were reformed by Viceroy Toledo in the I570s, and that, later on, constituted a model that continued to operate throughout the seventeenth century. The early colonial organization of labour in the Peruvian Viceroyalty was based partly on two important defining aspects: first, indirect rule, and second pre-existent, although substantively changed, forms of labour organization. As we will discuss in the final section, indirect rule implied a combination of two different types of labour relations. The first was between the beneficiary of the indigenous obligations (which could be an individual Spaniard, the Crown, or the church) and the native authorities responsible for those obligations that their communities had to fulfil. The second type was between the local native authorities and their people. This was the organizational key: indigenous people went to work in the mines or on the coca lands, paid their tributes in silver, or did whatever they had to, because of the relationship they had with the native authorities (Spanish: caciques) ${ }^{2}$ based on different types of reciprocity.

The Spanish took advantage of the Inca tributary system. According to Murra, ${ }^{3}$ before the conquest, all communities had to provide male and female labour to periodically perform a range of different tasks; they had to produce goods for the Inca authorities or for their own local authorities, and goods - offerings - for the gods. However, men from a specific group,

2. There were different levels of native authorities, and their regional names varied (curacas, bilacatas, mallku), but here we use the term cacique, meaning all those authorities collectively.

3. John V. Murra, La organización económica del Estado inca (Mexico, I989 [1978]). 
the yana, were in a different position, since they were separated from their communities and native authorities and were placed in the service of the Incas themselves, or in the service of other authorities. ${ }^{4}$ Their children inherited their status, and they were not obliged to perform the same periodic tasks that other natives were required to. This pre-Hispanic distinction between natives belonging to a community and the yanas persisted after the conquest, although in a colonial system.

What specific mechanisms were used by the Spanish to recruit native labour for their enterprises during the first few decades of the conquest? In general terms, indigenous slavery was forbidden soon after the demographic collapse in the Caribbean islands. The most widespread form of labour recruitment, especially in the Peruvian Viceroyalty, was the encomienda, legitimized by the Crown. This royally sanctioned institution entailed some of those Spaniards taking part in the conquest acquiring rights to receive tributes from a native authority and from any people subjected to it. In return, the beneficiary had to promote their welfare and guarantee that the indigenous people would embrace Christianity. The beneficiary was also obliged to contribute to the military defence of his jurisdiction of residence. ${ }^{5}$ Indigenous people were obliged to pay tributes in the form of goods, silver, gold, labour, or personal services. Right from the beginning, then, the Spanish could access the labour, and sometimes the capital, needed to develop agricultural, mining, and ranching enterprises. ${ }^{6}$ Most encomiendas benefited individuals, though a few were under the direct control of the Crown.

The second form of labour recruitment, which was present only in the Peruvian Viceroyalty, was the yanaconazgo. Although the yana population has its origins in the pre-Hispanic period, its significance changed completely during colonial times. Since the earliest decades of the conquest, they were a kind of servant and were not present in other regions - such as Mexico - at least not in the same number. ${ }^{7}$ There were different types of yanaconas, working for individuals, for the Crown, or for the church, although the largest group were those attached to the land, working on Spanish haciendas. From I 566 , they were obliged to pay tribute in cash to the Crown, but usually they did not pay at all.

4. John H. Rowe, "Inca Policies and Institutions Relating to the Cultural Unification of the Empire", in George A. Collier, Renato I. Rosaldo, and John D. Wirth (eds), The Inca and Aztec States, I 400-I 800: Anthropology and History (New York, I982), pp. 93-I I 8.

5. Barnadas, Charcas; Ana M. Presta, Encomienda, familia y negocios en Charcas colonial (Bolivia). Los encomenderos de La Plata I550-1600 (Lima, 2000).

6. Teodoro Hampe Martínez, "La Encomienda en el Perú en el siglo XVI", Histórica, 6:2 (1982), pp. 173-2 I6; Presta, Encomienda, familia y negocios.

7. Juan and Judith Villamarin, Indian Labor in Mainland Colonial Spanish America (Newark, DE, 1975). 
We want to stress two aspects of the organization of labour in this period that are important for our analysis. First, the encomienda implied a community and its native authority, which mediated the community's relationship with the encomendero, being a Spanish individual or the Crown. ${ }^{8}$ They preserved their land and their internal socio-political organization. The native authorities collected and paid their tributes to the encomendero in the form of silver and goods. Indigenous people included in the encomienda were also obliged to perform some public and private tasks, coordinated by their own native authority (such as carrying post, taking care of the upkeep of roads, building churches, and providing food for priests). After the extinction of their encomiendas, these indigenous people became royal tributaries and some of them were conscripted for the mita. Second, the yanaconas were separated from their communities; they had no land, nor did they recognize a native authority. ${ }^{9}$ They had to work for Spanish individuals, in mines, houses, on haciendas, or for the church. In most cases, they served the Spanish, without any mediation, but there were also yanaconas working for themselves, especially in urban contexts. They were not obliged to take part in the mita, nor bound by other collective obligations. Until i 566 , the yanaconas did not have to pay tribute to the Crown.

These two forms of labour organization were the most important in terms of numbers involved, and because they were official. Moreover, many of those who belonged to an encomienda were forced to fulfil colonial obligations only part of their time, depending on the community, the tasks they had to undertake, and their status. Not all indigenous individuals were necessarily included in those forms, and in a way they were "free"; there were some who could work for themselves, the most important of them being traders and artisans, who were inside the colonial economy but relatively independent.

\section{MINING AND LABOUR IN THE ANDES: VICEROY TOLEDO}

From the mid-sixteenth century, and almost until the present, the Americas produced most of the world's silver and gold. Between i 550 and I 800 , Mexico and South America accounted for over eighty per cent of the world's silver production, and over seventy per cent of all gold production. ${ }^{1 \circ}$ During the

8. In this article, we understand "community" to be a colonial construction. Some encomiendas, therefore, did not have the same organization or composition as the pre-Hispanic groups.

9. There were some yanacona authorities in the sixteenth century that emerged in the colonial context.

I0. Harry E. Cross, "South American Bullion Production and Export, I550-1750", in J.F. Richards (ed.), Precious Metals in the Later Medieval and Early Modern Worlds (Durham, NC, I983), pp. 397-424. 
sixteenth and seventeenth centuries, the Viceroyalty of Peru was notable for its mining production, while the Viceroyalty of New Spain was the most important mining region during the eighteenth century. One feature that distinguished these two places was the centrality of a unique mine in Peru: Potosí. During its heyday, it accounted for over ninety per cent of the Viceroyalty's production. Its silver production was so important that, even when in decline, it continued to dominate global Spanish-American

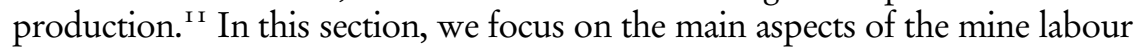
system at Potosí, including both free and coercive labour. ${ }^{\mathrm{I2}}$ We suggest that, directly or indirectly, mining was the activity that organized the colonial labour world, not only in Charcas, but throughout the Viceroyalty of Peru.

In the context of a Crown besieged by debt, the extraction of precious metals was a royal priority. Within this context, towards the end of the sixteenth century Viceroy Toledo introduced a range of reform measures. Firstly, these reforms aimed to increase Peruvian silver production, which had started to decline in the I560s because of the extinction of the highgrade ores. To achieve this, silver was amalgamated with mercury and a system of lakes built in order to supply the silver refineries (ingenios). ${ }^{\mathrm{I}}{ }^{3}$ Further, a compulsory labour system, the mita, was introduced for Potosí silver production. ${ }^{\mathrm{I}}$

Secondly, the reforms tried to increase control over the indigenous population, with varying degrees of success. This was effected through the so-called process of reducción, an attempt to concentrate in colonial towns the indigenous population living in dispersed settlements. This process affected more than one million people, and it aimed to make more effective the organization and fulfilment of colonial obligations, being both tribute and mita, as well as to improve evangelization and to impose a cultural model through European urban life patterns.

I I. Richard L. Garner, "Long-Term Silver Mining Trends in Spanish America: A Comparative Analysis of Peru and Mexico", American Historical Review, 93:4 (1988), pp. 898-935.

I 2. Various aspects of Potosi's history have been studied by many authors, whose findings offer a collective knowledge that has been essential to our article. Otherwise, it would have been neither possible to cover so many of the subjects necessary to help us understand the early colonial process, nor to examine all the disparate documentary sources. A recent review can be found in Paula Zagalsky, "La mita de Potosí: una imposición colonial invariable en un contexto de múltiples trasformaciones (siglos XVI-XVII; Charcas, Virreinato del Perú)", Chungara, 46:3 (2014), pp. 375-395. Some of the subjects mentioned in this section have been widely analysed in Raquel Gil Montero, "Free and Unfree Labour in the Colonial Andes in the Sixteenth and Seventeenth Centuries", International Review of Social History, 56 Special Issue 19, The Joy and Pain of Work: Global Attitudes and Valuations, I 500-1650 (201 I), pp. 297-3 I 8.

I3. The new phase made possible by amalgam technology implied that the social means of production were almost completely concentrated in Spanish hands.

I4. Peter Bakewell, Miners of the Red Mountain: Indian Labour in Potosi, I545-1650 (Albuquerque, NM, 1984). Jeffrey A. Cole, The Potosi Mita, I573-1700: Compulsory Indian Labor in the Andes (Stanford, CA, 1985 ). 
Thirdly, Viceroy Toledo massively monetized the tributary system. This system calculated the tribute per capita for the male indigenous tributary population in each repartimiento de indios (fiscal and administrative unit), but responsibility for payment lay with the caciques. ${ }^{\text {Is }}$ This monetized tribute obliged indigenous people, one way or another, to participate in commodified relationships, offering their products in the market or their labour in exchange for money. The labour relationships, even those mediated by money, could be both voluntary and coercive. ${ }^{16}$ In order to achieve these three main goals, Viceroy Toledo developed a fourth measure: a general visita, or inspection of the Viceroyalty, which recorded the number of individuals and their resources. The inspection played a key role in the reconfiguration process and in the imposition of a new order that involved the mita system, the payment of tributes, and the relocation of the indigenous population to new rural towns.

The characteristics of Potosís mine labour system have been widely studied, so we will merely summarize its central elements here. The Potosí mita was a state-coordinated form of draft labour, systematically organized since I 573 . Its major objective was to reorganize mine labour according to royal needs and the increasing political power of the state. Toledo's mining mita had pre-Hispanic precedents: the system was inspired by how the Incas had organized labour. Toledo's mining mita also had colonial antecedents taken from the first period of Potosí silver production, then dominated by native technology known as the buayra stage. ${ }^{17}$

The mita system established the forced migration to Potosí of a percentage of the male indigenous tributaries, mitayos, and their families for one year from the sixteen highland corregimientos (provinces) in the region between Cuzco and the southern border of present-day Bolivia (Figure I). In I 575 , Toledo determined the percentages of mitayos each region should send annually: between thirteen per cent and seventeen per cent of their tributaries. Different viceroys established the annual total, "mita gruesa", which varied only during the initial years of the system: between I 573 and I 575, the number of mitayos varied from about 9,500 to around I I,000; but from I 578 to the I680s, it was fixed at around I4,000. The mita labour system divided the annual contingent into thirds: one-third were

I s. In the early colonial period, repartimientos de indios were groups of native people assigned to a certain encomendero, so they were fiscal and administrative units. In addition, since the seventeenth century they were considered territorial units being parts of a province's district.

I6. Carlos S. Assadourian, "La despoblación indígena en Perú y Nueva España durante el siglo XVI y la formación de la economía colonial”, Historia Mexicana, 38:3 (1989), pp. 419-453.

I7. Idem, "La producción de la mercancía dinero en la formación del mercado interno colonial. El caso del espacio peruano, siglo XVI", in Enrique Florescano (ed.), Ensayos sobre el desarrollo económico en México y América latina (I 500-1975) (Mexico, 1979), pp. 223-292. Bakewell, Miners of the Red Mountain. Gil Montero, "Free and Unfree Labour". 
obliged to work weekly, while the other two-thirds rested, although only theoretically. ${ }^{18}$ Mitayos were obliged to work weekly for a limited number of Spanish owners of mines and mills. ${ }^{19}$ In I 575, Viceroy Toledo established the mita "capitanias" to organize and ensure mitayo labour in Potosí. This institution appointed native leaders, who were responsible for the mobility and presence of forced mine labourers. In the beginning, this was a position of great power and prestige, but by the seventeenth century it had become a heavy and difficult burden to bear.

The polity fixed the wages of forced labourers at a rate below those paid to "free" labourers. In theory, wages were paid in money and were insufficient to ensure the reproduction of labour power. In addition to wages, mitayos also had resources from their communities of origin, which thereby subsidized colonial mining production. ${ }^{20}$ Mitayos women also contributed to their household economy by working in the urban markets. ${ }^{2 \mathrm{I}}$ Apart from paying their tributes (almost ninety per cent of their income), mitayos were also obliged to contribute part of their wages to pay the salaries of royal officials, mita captains, and hospitals. ${ }^{22}$ Finally, they needed money to pay for their individual and family livelihood, such as food, clothes, housing, and candles for the mines. Clearly, they had no choice but to look for other job opportunities as "free" labourers during their period of "rest". ${ }^{23}$ This guaranteed mine owners a permanent supply of "free" labour. ${ }^{24}$ Assadourian has estimated that at the beginning of the seventeenth century - during the mining boom in Potosí - seventy per cent of the labour force was hired and thirty per cent was forced. ${ }^{25}$ Hired labour was important in terms of numbers, particularly in specialized and better-paid tasks. ${ }^{26}$ The mita could be fulfilled in person, but substitution (conmutación) was also permitted. This meant that it was possible to pay a fixed sum of money for each absent mitayo. With that money, termed "silver Indian", it was possible to hire and pay a labourer. However, the

I 8. This system of "thirds" was not effective and, presumably during the seventeenth century, it was replaced by one in which the contingent was divided into two (Cole, The Potosi Mita).

19. This system excluded many Spaniards who arrived too "late" to benefit from this source of labour. Many of those excluded submitted complaints centred on the mita, even questioning it strongly in the second half of the seventeenth century.

20. Assadourian, "La producción de la mercancía".

2. Jane Mangan, Trading Roles: Gender, Ethnicity, and the Urban Economy in Colonial Potosi

(Durham, NC [etc.], 2005).

22. Assadourian, "La producción de la mercancía".

23. Bakewell, Miners of the Red Mountain.

24. Assadourian, "La producción de la mercancía".

25. Ibid.

26. Ibid., pp. 252-257; Enrique Tandeter, Coacción y mercado. La minería de la plata en el Potosí colonial, I692-I 826 (Buenos Aires, I992); Paula Zagalsky, "Trabajadores indígenas mineros en el Cerro Rico de Potosí. Tras los rastros de sus prácticas laborales (siglos XVI y XVII)”, Revista Mundos do Trabalho, 6:12 (2014), pp. 55-82. 
money paid in compensation was not always used to hire a replacement; often it remained in the pockets of the Spanish beneficiaries of the mita (mine owners and mill owners).

There are two different ways of evaluating the numbers covered by the mita. On the one hand, we have the official list of annual mitayos, that is the estimated number of mitayos forced to work in the mines and mills of Potosí; on the other hand, we can also consider the effective number of mitayos who really went there and worked. At around I 4,000 per annum the estimated number was very stable until the end of the seventeenth century, but the effective numbers - information not easily found and not systematic $^{27}$ - corresponded closely to silver production: they fell throughout the century. It was not until the government of Viceroy La Palata in the late $\mathrm{r} 680$ s that the theoretical and effective numbers tended to coincide (Figure 2).

Only Potosí and a few other mining centres benefited from the mita, which means that, in almost all other mining camps, hired labour prevailed. These kinds of labourers quickly increased in number from the last quarter of the sixteenth century onwards, partly because of growing demand for specialists in mercury amalgam technology and partly because of the end of the encomienda system. ${ }^{28}$ Hired and paid labour, however, did not mean a modern labour market. The owners of mines and mills organized their labour force in such a way as to combine mechanisms of attraction, more-or-less forced recruitment methods, and forced retention of labourers. The two principal ways of attracting people were the combination of better wages, something possible in the new rich mines, and the opportunity labourers had to work for themselves during the weekends. ${ }^{29}$

Many testimonies and ordinances indicate that the notion of "hired" was interpreted liberally in relation to mine labour: coercion was very common, and it was permitted under various circumstances because mining contributed to the royal "fifth" (quinto) - a tax imposed on silver production. The Spanish, for example, had the right to take indigenous people living in the vicinity of their mines and oblige them to work.

27. Tandeter, Coacción y Mercado. Cole, The Potosí Mita.

28. Bakewell, Miners of the Red Mountain.

29. Zulawski suggested that the wages were necessary, but not sufficient, to tempt labourers, and that they were probably only half of what workers were capable of earning had they been allowed to prospect for minerals themselves. Ann Zulawski, "Forasteros y yanaconas. La mano de obra de un centro minero en el siglo XVII", in Olivia Harris, Brooke Larson, and Enrique Tandeter (eds), La participación indígena en los mercados surandinos. Estrategias y reproducción social. Siglos XVI a $X X$ (La Paz, I987), pp. I 59-I92. María C. Gavira Márquez, "Reclutamiento y remuneración de la mano de obra minera en Oruro, 1750-1810", Anuario de Estudios Americanos, 57:I (2000), pp. 223-250. Gil Montero, "Free and Unfree Labour". Raquel Gil Montero, "Mecanismos de reclutamiento indígena en la minería de plata. Lípez (sur de la actual Bolivia), siglo XVII”, Revista América Latina en la Historia Económica, 2 I:I (2014), pp. 5-30. 

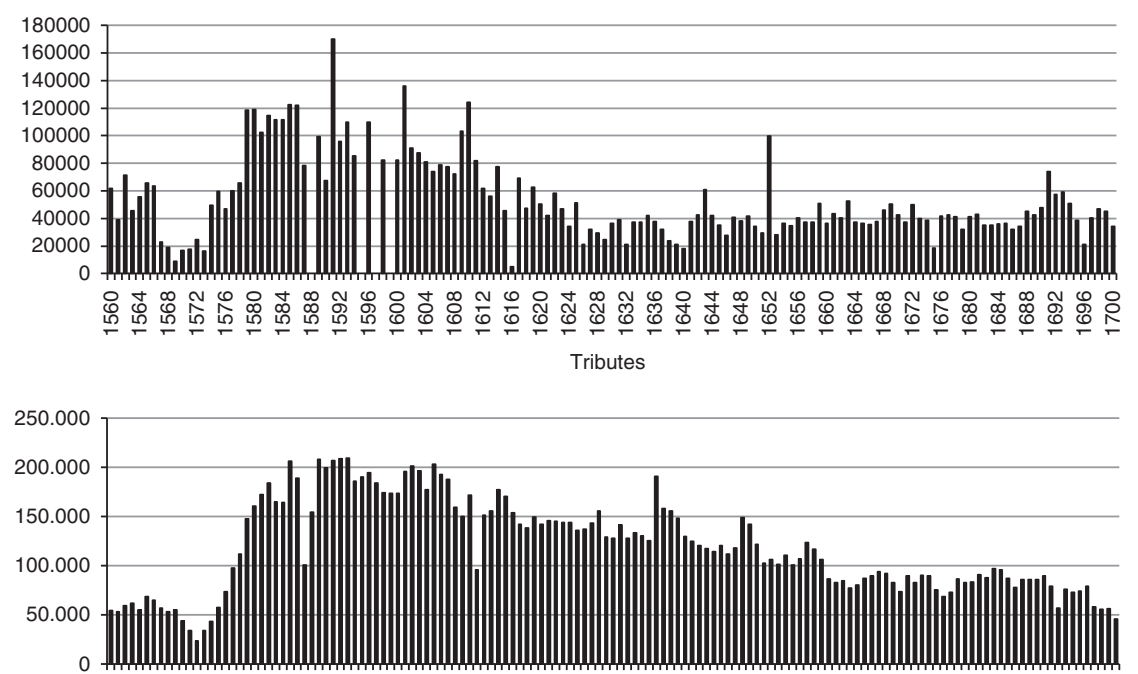

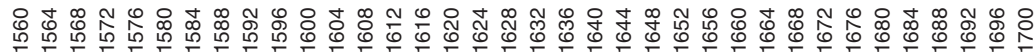
Silver production

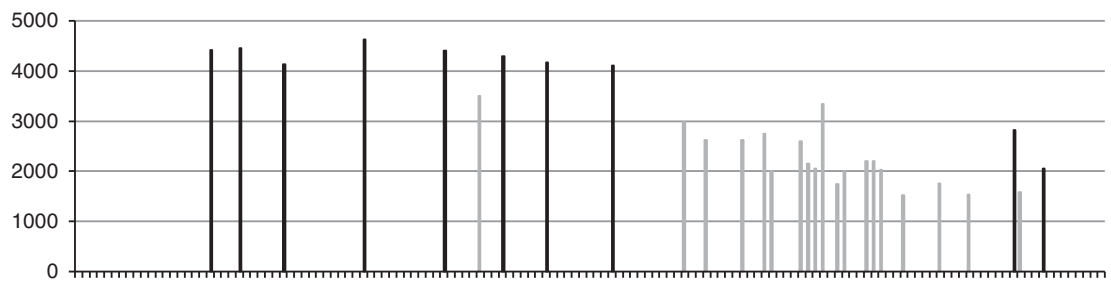

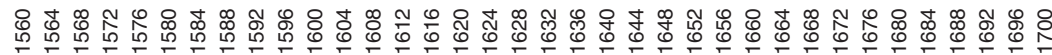

Mita: theoretical (in black) and effective (in grey)

Figure 2. Tributes, silver production, and the mita, Potosí, i 560-1700.

Sources: Tributes (in pesos) and silver production (in kilos), TePaske (http://www.insidemydesk. com/hdd.html); mita (number of mitayos), Cole, The Potosi Mita, pp. 4I, 72; Tandeter, Coacción y mercado, pp. 39-48.

This activity was sometimes known as "hunting". ${ }^{\circ}$ This right was already enshrined in Toledo's ordinances. ${ }^{3 \mathrm{I}}$ There were other practices in relation to labourers, including the abduction or retention of their wives, and the pursuit and capture of runaways. There are documents that record the "sale" by native authorities of labourers; we have treated then as hired

30. Gil Montero, "Mecanismos de reclutamiento".

31. Mining Ordinances, Ordinance III, Francisco de Toledo, Relaciones de los Vireyes y Audiencias que han gobernado el Perú: Memorial y Ordenanzas de D. Francisco de Toledo, 4 vols (Lima, I 867), I, p. 274. 
labour. Working in a mine, however, meant the possibility of earning more money, principally for those who were specialists and could earn better wages. Many indigenous people acquired technical knowledge relating to the amalgam process in Potosí, and, with it, they could command higher wages in new mines such as Oruro and San Antonio de Lípez. ${ }^{32}$

\section{MITA, TRIBUTE, AND LABOUR: A DISCUSSION}

Toledo's enduring reforms profoundly changed the colonial reality. In our article, we stress the relevance of the mita in the organization of labour relations. This hypothesis is based on the number of people directly forced to work in the mines and mills, on mita's role in the mining boom at Potosí, and, principally, on the related migrations that modified the demography of the Viceroyalty and influenced almost all other forms of labour. The mita also occupied a central place in official concerns: it was present in debates, correspondence, and viceroys' reports, while the tribute lost importance. In our analysis, we reconsider some classic interpretations, focusing on the tribute, of the mechanisms that forced native peoples to work in colonial enterprises. These mechanism, we believe, were very important at the beginning of the colonial period, but over time they lost their centrality because of the transformation of the economy and society in the Peruvian Viceroyalty.

How did the Spanish oblige native populations to participate in the colonial economy as labour? Assadourian proposed a number of interpretations for the colonial period that have profoundly influenced the historiography, ${ }^{33}$ and we now re-evaluate them, focusing on labour and tribute. Assadourian wrote that the tributes indigenous people had to pay increased significantly, first with the inclusion of the yanaconas in I 566 and then with the reforms introduced by Viceroy Toledo, who augmented the value of the tributes each community had to pay and monetized them. ${ }^{34}$ These reforms pushed native people to sell their labour or goods, thus stimulating the internal economy and augmenting royal incomes. Demography and the economy - Assadourian argues - developed in reverse, at least until I630. Demography was the limiting factor in the growth of tributes: the size of the native population fell. This drove the government to put mining at the centre of its utilitarian politics. ${ }^{35}$ Assadourian analysed the shipments of silver to Spain and the increase in royal incomes as indicators of economic growth and of the increase in the tax burden. In particular, he emphasized the differential pressure on native

32. Gil Montero, "Mecanismos de reclutamiento".

33. Assadourian, "La despoblación indígena".

34. Ibid., p. 427.

35. Assadourian, "La despoblación indígena", p. 427. 
peoples, both in tributes and in labour, between Mexico and Peru, where the burden was much worse.

We base our discussion of Assadourian's hypothesis on TePaske's impressive work in collecting data on and interpreting royal income and expenditure in Spanish America. ${ }^{36}$ Drawing on his work, we used two sets of data taken from the records of Potosîs Caja Real: ${ }^{37}$ on tribute income and silver production. Tributes were an explicit component of royal income, unlike the other obligations that the native people had to fulfil, so we prioritized the colonial obligation, which can be analysed as serial data and quantified. We know that other demands were made that are difficult to quantify. For example, the forced acquisition of goods, where native people were compelled to buy unnecessary goods sold to them by local authorities at high prices; services that natives owed to their authorities, such as transport using their own animals; and food and services they owed to the priests. These are not included here. The data on silver production were processed by TePaske, based on the Potosí royal incomes (Figure 2). We also looked for data on the mita, both theoretical and effective. The data available are not all of the same quality, but we can observe a general tendency. Finally, we added information on population (Table 2).

In Potosí, tributes and mining taxes accounted for ninety per cent of royal income during the sixteenth and seventeenth centuries. ${ }^{38}$ Serial data on both show how they developed differently over time. To explain this variation, Klein suggested that, in general, the royal fifth tax was linked to silver production, while tributes followed indigenous demography. ${ }^{39}$

However, the tribute data show a closer relationship to colonial politics. We observed four cycles in the tribute series, although a small variation at the end of the period could be interpreted as a fifth cycle (Table I). Before Toledo, tribute income accounts for just thirteen per cent of total income reaching the royal treasury, and it was not especially important, measured in pesos.

36. The data assembled by TePaske and an important group of researchers are available at: http:// www.insidemydesk.com/hdd.html, last accessed 2 December 201 5 . Part of the published analysis starts in 1680. See, for example, Herbert Klein, The American Finances of the Spanish Empire: Royal Income and Expenditures in Colonial Mexico, Peru, and Bolivia, I680-I809 (Albuquerque, NM, 1998). For a more extended analysis, see Bernard Slicher van Bath, Real Hacienda y economía en Hispanoamérica, I54I-I820 (Amsterdam, I989). For a critical study, see Raquel Gil Montero, "El tributo andino reinterpretado. El caso del corregimiento de Lípez", European Review of Latin American and Caribbean Studies, 99 (2015), pp. 69-88.

37. The Caja Real was the royal treasury, which recorded all royal income and expenditure. Some provinces, and other minor jurisdictions, had one. Potosîs Caja Real included records not only for the city, but also for the province (Porco) in which Potosí was located and for other neighbouring provinces (including Lípez and Chichas).

38. Here, we also included income from quicksilver, which was a monopoly of the Crown. Klein, The American Finances.

39. Ibid. 
At that point, few repartimientos de indios were paying in Potosí, and those that did paid infrequently. With Toledo, three important changes occurred: it was made compulsory for the yanaconas to pay; most of the encomiendas lapsed and the tributes associated with these rights reverted to the Crown; and there was an important and successful official effort to oblige all tributaries to comply with their obligations. Royal incomes increased in a clear context of population decline, as Assadourian noted. However, from the beginning of the seventeenth century tributes started to lose their relevance compared with the mita, not only for the royal treasury, but also for the authorities. One sees a clear and rapid decrease in tribute income. The fourth cycle shows relative stability in those incomes, which were at their lowest level during colonial times, even though the number of repartimientos obliged to pay the tribute was greater. The last cycle was brief, and showed a sharp decrease in expected repartimientos and a slight, but significant, increase in tributes: those were the years of La Palata's general inspection..$^{4}$

Toledo's government marked a period of unprecedented involvement by the colonial state and its agents, organizing and controlling tributaries. Their presence led to a temporary increase in tribute income. However, at that time, the principal concern was to organize the collection of the royal fifth ${ }^{4 \mathrm{I}}$ and so the state stopped pressing indigenous labourers in relation to tribute and instead continued to press them in relation to the mita. Table I shows that, over time, although more repartimientos were obliged to pay tributes to the Crown, not all of them did so every year. In Potosí, tributes lost their importance in terms of value, since taxes on mining production became the chief source of income.

Regarding the demographics of the seventeenth century (the second factor in Assadourian's argument), massive migrations in the Andes seemed to be related to mining activity since a large proportion of the labour force was directly or indirectly involved in silver production. When it comes to assessing this relationship, the worst problem we face is that most of the regional silver boom took place between the two general inspections (Toledo's in the I570s, and La Palata's in the I680s) in which the Andes population was enumerated. A second problem is that those inspections excluded an important part of the indigenous population living in the cities that had emerged around centres of silver production. To compensate for this, we used other evidence that shows the direction of migration during the seventeenth century (Table 2), and this implies we need more than Potosí to understand that migration: we also need the mita. The evidence comprises two observations: first, that it was the

40. The cause of the decrease in the number of repartimientos expected to pay was a reorganization of the royal treasury: some of the repartimientos started to pay in 1609 in another Caja Real; some of them disappeared from the official records.

4I. The royal fifth accounted for two-thirds of total royal income in Potosí. 
Table I. Tributes: royal treasury of Potosi, I560-I700.

\begin{tabular}{ccccc}
\hline & $\begin{array}{c}\text { No. of } \\
\text { repartimientos } \\
\text { expected to pay* }\end{array}$ & $\begin{array}{c}\text { No. of repartimientos } \\
\text { that paid each year } \\
\text { (average) }\end{array}$ & $\begin{array}{c}\text { Tributes as } \\
\text { \% of total } \\
\text { income } \\
\text { (average) }\end{array}$ & $\begin{array}{c}\text { Tributes: average } \\
\text { total annual } \\
\text { payment (in } \\
\text { pesos ensayados) }\end{array}$ \\
\hline $1560-1573$ & 20 & 9 & 13 & 37,796 \\
$1574-1601$ & 31 & 19 & 9 & 96,349 \\
$1602-1626$ & 31 & 12 & 5 & 64,061 \\
$1627-1687$ & 38 & 11 & 4 & 38,080 \\
$1688-1700$ & 16 & 11 & 5 & 46,509 \\
\hline
\end{tabular}

Source: TePaske (http://www.insidemydesk.com/hdd.html)

* Yanaconas were not included

Table 2. Distribution of indigenous people recorded in the general inspections of Toledo and La Palata (\%)

\begin{tabular}{lcc}
\hline Regions & Toledo (1570s) & La Palata (1680s) \\
\hline Cuzco + Puno + Chucuito & 64 & 32 \\
La Paz & 17 & 27 \\
Charcas & 19 & 41 \\
\hline
\end{tabular}

Sources: Toledo (Noble David Cook, Tasa de la Visita General de Francisco de Toledo (Lima, I975)); La Palata (Ignacio González Casasnovas, Las dudas de la corona. La política de repartimientos para la minería de Potosi (I680-I732) (Madrid, 2000)).

region around Potosí that grew most; and, second, that the provinces that lost most in terms of population were those obliged to send mitayos.

Mining, mita, and migrations were strongly connected, as many migrants from the northern mita provinces did not return to their homes, and stayed in Potosí, as we can see in Table 2, which summarizes the demographic changes that occurred in the Peruvian Viceroyalty.

To explain the mechanisms developed by the colonial state and that permitted this kind of migration - probably as an undesired effect - we propose to separate tributes from other forms of labour, and to examine what happened between the I 570 s and 1680 s. $^{42}$ In some cases, trends coincided, but in many others they did not. We found three different situations: one in which some tributaries had to pay their tributes in money, and they worked to earn this money; another in which they had to work as forced labourers (mitayos) and to pay their tributes as well;

42. Andean historiography generally analysed mita and tributes together with the other obligations that indigenous people had to pay (in the form of labour for example), regarding them all as part of the "tribute" they had to pay as Crown subjects. Zagalsky, "La mita de Potosí". 
and a third in which they sometimes had to work and were not obliged to pay tributes in money, as was the case with the yanaconas mentioned earlier.

Regarding tributes, Toledo reinforced a tendency that had already begun and that might explain the timing of migration: most of the tributes were paid to the Crown at the royal treasury and not to the private sector encomenderos. This was a consequence of Crown policy, started in the is6os, to eliminate the social, political, and material power of the encomenderos. As a result, indigenous people were no longer subject to a particular beneficiary, a situation that allowed labour to migrate and to be recruited for the most important activity benefiting the Crown: mining. In this context, Philip II said about the mine labourers: "The profit that one of these natives [mine labourer] generates is greater than that given by twenty tributaries". ${ }^{43}$ Mobility disfavoured the control that native authorities had on their people and thus affected the payment of tributes. However, although the officials knew from the beginning about the decrease in these incomes and about the massive migration, they took no action until the arrival of La Palata in the I680s.

Geographical mobility was, and still is, important in the mine labour world. We believe that two factors permitted and promoted mobility during the seventeenth century: the fact that the tributes were paid to the Crown, and not to private individuals; and the organization of the mita. Becoming royal tributaries, without personal links to a particular Spaniard, allowed indigenous caciques, groups, and people to "choose" where to sell their labour or goods, and to earn money to fulfil their obligations. Further, the power that Potosí mine owners and the authorities had at that time allowed them to prioritize the mita, arguing that it helped them to increase the royal fifth. This had a practical result: tributes decreased dramatically during this period, but the authorities took no action.

There were two types of labour: one mobile and one attached to the land. The first group, people affected by the mita, who fled - either to avoid the obligation or to find money for a substitute - provided labour for various activities that did not rely on forced labour: these activities included work on estates, in other mining centres, and in the transportation of goods to supply the important urban market that was developing during the seventeenth century. The second group was established by the agricultural estates, which promoted greater geographical stability for labourers, using a range of mechanisms to bind them to the land. One such mechanism involved Spanish landowners paying the tributes to the Crown and the indigenous labourers being indebted to them in return. Another involved 
landowners attracting or accepting fugitive tributary natives, who became yanaconas, thus establishing a personal relationship with the Spanish and becoming less free to move.

There has been a conflicting debate about the demographic crisis at the end of our period, in the I680s and I690s. On the one hand, the royal authorities claimed that the principal cause of the decrease in tribute income and in the number of mitayos was the indigenous people running away and avoiding their colonial obligations. On the other hand, indigenous organizers of the mita in Potosí maintained that people were obliged to flee from their rural towns because of abuse by the caciques, the local Spanish authorities, and because their lands had been sold. Moreover, during the seventeenth century, further burdens were added to the existing ones tributes and mita - already imposed on the natives. One of these became the most important: the forced acquisition of goods, sold by local Spanish authorities to the natives, from the first half of the seventeenth century. Indigenous people were forced to buy non-useful and very expensive goods sold by the local authorities, a practice legalized by the Crown in the i750s. This practice had its origins in the seventeenth century, when the Crown began to sell official positions, especially that of local governor. The appointee then attempted to recover the money paid to the Crown by selling goods to the tributaries.

Although beyond our period, a description of what happened during the eighteenth century helps to put the previous two centuries into a broader context. According to various sources, during the first half of the eighteenth century mita substitution and the compulsory purchase of goods by indigenous people were the most oppressive obligations for the royal tributaries. In this context, royal officials also made various attempts to oblige indigenous people to pay their tributes regularly. ${ }^{44}$ In the context of the new reforms introduced by the Crown, the native response to all these pressures was the increase in violence that began in the 1740 s, culminating in massive rebellion during the 1780 s. The compulsory purchase of goods was subsequently forbidden, and the way tributes were paid was radically reformed: people had to pay per capita, and the tribute payable was related to their place of residence and not their place of origin. The indirect forms of labour control discussed earlier lost much of their significance. As a result, in the late 1780 s, for the first time in the colonial history of Charcas, the value of the tribute collected by the royal officials exceeded that of silver production. The importance of the

44. The context was actually more complex than this. See Sergio Serulnikov, Subverting Colonial Authority: Challenges to Spanish Rule in Eighteenth-Century Southern Andes (Durham, 2003). The Bourbon monarchs made important reforms during the second half of the eighteenth century which modified the so-called colonial pact and significantly affected the local population (not only the indigenous people). 
tribute grew significantly and became the main source of Crown income in the Andes.

\section{COLONIAL POLICIES AND SHIFTS IN LABOUR RELATIONS}

In presenting our case study of the definitions of labour relations proposed by the Collab, we want to stress, first, that all the labour relations we have noted existed in a colonial context. This context influenced all labour relations, especially those of indigenous peoples. Second, we use the term "state" in a broader sense, as proposed by the editors, and, of course, as distinct from the "nation state". During colonial times in Spanish America, political power was devolved to various decentralized poles, often with conflicting interests. However, there was a significant difference between what we have called private individuals and the authorities, although in many cases they were one and the same. Third, one of the characteristics of the relationship between conquerors and natives was the role of indirect rule. This characteristic partly explains the survival of Andean communities, because they maintained their right to organize themselves - at least at some levels - and retained part of their original lands and resources - in theory - as long as they fulfilled their colonial obligations, namely tribute and mita. Platt proposed the notion of "pact" to understand this relationship. ${ }^{45}$

In what follows, we analyse each tributary category using the Collaboratory's taxonomy (Figure 3). Broadly speaking, almost all the population living on communal land were household producers, leading and kin, at least part of the year. In addition, and because of their reciprocal relationships, they also had to fulfil communal obligations, such as tribute and mita. Then, part of the year and sometimes during a whole year, a percentage of the tributaries and their families migrated to Potosí to work in the mines or mills, or they went elsewhere to earn the money they needed to meet their communal obligations. People belonging to a community (i.e. everybody except the yanaconas and those we have termed "free" indigenous people) had to fulfil jointly all the many obligations, as we have seen above, and not just the tributes. The cacique was responsible for fulfilling these obligations to the colonial authorities. Some wealthier groups or people were able to avoid selling their labour: instead, they sold their goods in urban markets, went as merchants to various parts of the Viceroyalty, or had enough llamas to transport their goods or those of others.

All the relationships we have noted in the previous paragraph were within the ethnic group; however, indigenous peoples also had labour relations with the Spanish. In the mita system, for example, we find a combination of inter- and intra-ethnic relations. On the one hand, there

45. Tristan Platt, Estado boliviano y ayllu andino (Lima, 1982). 


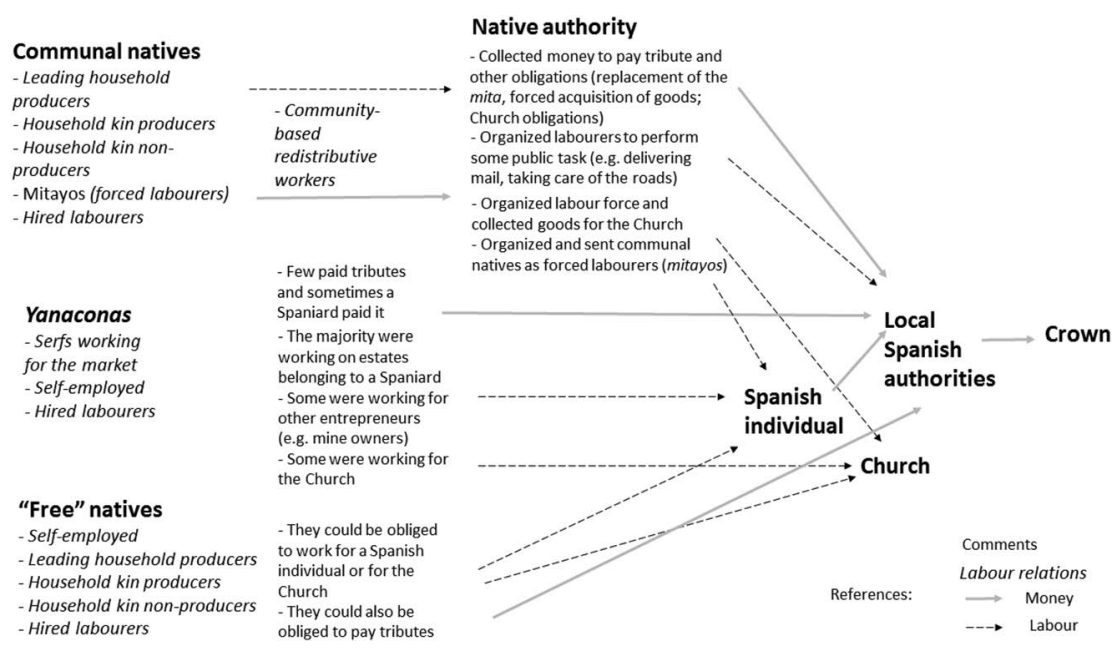

Figure 3. Overview of labour relations during the seventeenth century, Charcas.

were the colonial obligations all indigenous peoples had as Crown subjects that legitimized the state-coordinated form of draft labour organized by Viceroy Toledo for the benefit of individual Spaniards; on the other, there was the asymmetrical reciprocal relationship indigenous people had with their native authority, which forced them to fulfil their obligations. All indigenous individuals were Crown subjects, but this relationship was mediated by their native authorities.

Although mita was not tributary labour in the sense proposed by the Collaboratory - because the polities did not benefit directly, as the mines were exploited not by the state but by individual Spaniards - initially only royal authorities had the power to force indigenous people to migrate and to work in mining, coordinated through their caciques. The benefit to the Crown was indirect: indigenous labour produced silver, and, owing to the royal fifth tax paid by private silver producers, this was the main source of the increase in royal income.

The state regulated the amount of money that mitayos received for their labour from individual Spaniards. This amount was less than the wages paid to hired labourers, and when the mita was first organized it was calculated per day. However, during the seventeenth century the miners regulated the mitayo's weekly work, imposing a production quota, and the money they actually received was therefore less than the level theoretically set by the state. As mitayos they had to pay their tribute, for their food, all the equipment needed for their work, for the hospital, and the salaries of their priests and of the colonial authorities. 
There were various types of indigenous people involved in Potosís mining activities: forced labourers (mitayos) as well as "hired" labourers and yanaconas belonging to the Crown. All of them were Crown subjects, although not all were obliged to work in the mines. Why did indigenous people who were not mitayos go to Potosí or to other mines? Colonial relationships explain this. For example, Spanish miners had the right to oblige a small number of indigenous people living close to their mines to work there, just because they were Crown subjects. In other mining centres in south Charcas we found people who had been forced to stay, by being locked inside a room for the night, or because their wives and children were prevented from leaving. ${ }^{46}$

What we have here called "hired" labourers were people who went to the mines, attracted by the incomes they could earn there. They were usually "well-paid" skilled labourers, though it would be more accurate to say "better paid"; they were sometimes the same mitayos, working in their free time. Although they were free to move to other places and mines, they were not really free to decide to stay in their communities if they wanted. They could also be obliged to stay in a mining camp against their will. As we have already seen, they, too, had to find money to pay their obligations and not only for their survival: their reciprocal relationships with their communities "forced" them to go.

Among the yanaconas, we found no indirect rule, as they had no reciprocal obligations to their communities. However, they were also Crown subjects. In almost all mining centres, there were three different types of yanaconas: some worked for particular individuals (as a kind of servant), others for themselves (forced only to pay the tribute to the Crown), while others worked for the church (and paid tribute to the Crown).

There were also indigenous peoples living in places other than the communal lands, mines, and estates we have described. Many of them lived in the cities, sometimes with strong relationships to their communities, through paying their tributes, sending money for the mita substitute, or for other reasons; there was sometimes no such relationship. The latter were "free" indigenous people, who did not recognize a native authority, who did not work for a Spaniard, fixed to the land as yanaconas, and who did not pay tribute. They lived, avoiding obligations, on the margins, but they played a role in the colonial economy as traders or muleteers; sometimes, they worked in peripheral lands or mines, or as highland pastoralists. In the seventeenth century they were few in number, but by no means insignificant.

In summarizing the role of the state in labour relations, we would stress some of the factors that defined those relations. The first is that all 
indigenous people were subjects of the Spanish Crown, and that allowed private individuals and various authorities to force them to work. The state defined many of the tasks that almost all tributaries living in communal lands had to perform. They were also obliged, by the state, to send some of their men to work in specific mines and mills, and to pay their tributes to the Crown. The state set the wages that mitayos received and, in general, all obligations relating to this particular form of labour. Other non-official obligations, such as paying for their substitutes in the mita, or buying the obligatory goods sold to them by the local governor, could be considered indirect methods to force them to acquire money, through the sale of their labour or goods. Finally, the passive role of the authorities was also important: for example, like the encomenderos before them, royal officials did not control the tribute indigenous people had to pay to the Crown, or their spatial movements.

\section{CONCLUSIONS}

Right from the beginning of the conquest, the Spanish took advantage of the Inca's organization of labour. However, in a colonial context labour relations changed significantly. The architect of the changes that affected those relations until the end of the eighteenth century, and, in some respects, until independence, was Viceroy Francisco de Toledo. In this article, we have stressed four aspects of his reforms that were important for the new configuration of labour relations: the organization of the mita, the extinction of the encomiendas, the increase in the amount each community had to pay, and the obligation to pay in money. The reforms freed the tributaries from their encomenderos and permitted the massive migrations that took place from the seventeenth century onwards.

Why would a native leave his land and work for the conquerors? The historiography traditionally argues that the increase in the tribute, and the obligation to pay it in money, forced them to migrate and to look for ways to earn money in order to pay it. This is, of course, part of the answer. However, we have seen that there were also indigenous people who were not obliged to pay, but instead required to work for the Spaniards (yanaconas); further, the obligations involved more than paying tributes, and the other obligations were sometimes more important. It was the colonial relationship indigenous people had with the Crown that legitimized the different forms of direct and indirect coercion.

Direct coercion was exerted, for example, through the mita system, and through some royal labour regulations. Indirect coercion is more difficult to identify. Indigenous peoples, and, more specifically, those peoples of more limited means, were forced to leave their land and to look for ways to earn money to fulfil their colonial obligations. There were at least three reasons for this: the need to pay for substitutes for the mita, the obligation 
to buy goods sold by the local governors, and the tributes themselves. The latter lost their importance during the seventeenth century, while the first two became more important. Regarding the Collaboratory's taxonomy, we want to stress that, although the state regulated the tasks and identity of labourers, the major beneficiaries were private individuals.

Why did indigenous peoples fulfil their obligations? The key factor was indirect rule: those natives belonging to a community wanted to retain their rights by collaborating with their communities, paying their tributes, and meeting all other obligations. In exchange, they could organize their own government and keep their lands.

Natives who did not belong to a community, typically the yanaconas, did not have reciprocal labour relations and communal obligations. Some of them had inherited their yanacona status and worked for a Spaniard right from the start of the conquest. Some had tried to escape their obligations, principally the mita, by running away and ended up as yanaconas on estates or working in other enterprises. Royal officials did not force them to return to their communities, partly because there were an increasing number of Spanish landowners and mining entrepreneurs who did not have the advantage of forced labour - such as the mitayos - and who therefore needed such labour. 